\title{
Effect of storage on the properties of vermicompost generated from paper waste: with focus on pre-drying and extent of sealing
}

\author{
M. Karthikeyan $\cdot$ S. Gajalakshmi $\cdot$ S. A. Abbasi
}

Received: 27 January 2014/ Accepted: 30 June 2014/Published online: 7 August 2014

(C) The Author(s) 2014. This article is published with open access at Springerlink.com

\begin{abstract}
The beneficial effects of vermicast on soil fertility in general, and agriculture in particular, are widely recognized, but there are no reports on the effect of storage on vermicast quality. The present study is an attempt to cover this knowledge gap as it may assist in the formulation of guidelines for packaging and storing of vermicast in a manner that preserves the cast's fertilizer value. Vermicast generated from paper waste was packed in airtight and partially sealed bags with and without pre-drying for $24 \mathrm{~h}$. Changes in several physical, chemical, and biological properties of the castings were monitored for 3 months with weekly assessments. The results reveal that the beneficial properties of vermicast were the highest when it was fresh. There was deterioration on storage, which can be minimized if the castings are contained in airtight bags after pre-drying the casts.
\end{abstract}

Keywords Vermicast properties · Vermicast storage . Vermicast packing $\cdot$ Eudrilus eugeniae . Paper waste

\begin{tabular}{|c|c|}
\hline \multicolumn{2}{|c|}{ Abbreviations } \\
\hline AUD & Fresh vermicast stored in airtight bags \\
\hline APD & $\begin{array}{l}\text { Vermicast pre-dried for } 24 \mathrm{~h} \text { stored in airtight } \\
\text { bags }\end{array}$ \\
\hline PUD & Fresh vermicast stored in partially sealed bags \\
\hline PPD & $\begin{array}{l}\text { Vermicast pre-dried for } 24 \mathrm{~h} \text { stored in partially } \\
\text { sealed bags }\end{array}$ \\
\hline WHC & Water holding capacity \\
\hline WFPS & Water-filled porosity \\
\hline
\end{tabular}

M. Karthikeyan · S. Gajalakshmi · S. A. Abbasi $(\bowtie)$ Centre for Pollution Control and Environmental Engineering, Pondicherry University, Chinnakalapet, Puducherry 605014, India

e-mail: prof.s.a.abbasi@gmail.com

$\begin{array}{ll}\mathrm{C}_{\text {org }} & \text { Total organic carbon } \\ \mathrm{C}_{\text {dis }} & \text { Dissolved organic carbon } \\ \mathrm{N}_{\text {tot }} & \text { Total nitrogen } \\ \mathrm{NH}_{4}{ }^{+}-\mathrm{N} & \text { Ammonium nitrogen } \\ \mathrm{NO}_{3}{ }^{-}-\mathrm{N} & \text { Nitrate nitrogen } \\ \mathrm{K}_{\text {ext }} & \text { Extractable potassium } \\ \mathrm{Ca}_{\text {ext }} & \text { Extractable calcium } \\ \mathrm{Na}_{\text {ext }} & \text { Extractable sodium } \\ \mathrm{P}_{\text {ext }} & \text { Extractable phosphorus } \\ \mathrm{SO}_{4}{ }^{2-}-\mathrm{S} & \text { Sulfate } \\ \text { DHA } & \text { Dehydrogenase activity } \\ \text { BGA } & \text { } 3 \text {-Glucosidase activity } \\ \text { APA } & \text { Alkaline phosphatase activity } \\ \text { ASA } & \text { Arylsulphatase activity } \\ \text { CEA } & \text { Cellulase activity } \\ \text { URA } & \text { Urease activity } \\ \mathrm{C}_{\text {mic }} & \text { Microbial biomass carbon }\end{array}$

\section{Introduction}

The vermicast that is deposited by the earthworms on the soil is known to fertilize the soil as well as influence its physical and chemical properties in a way that is beneficial to plant growth in particular and soil environment in general. Due to this realization, several studies have been conducted on the fate of vermicast, especially how the biological, chemical, and physical attributes of the vermicast change with time [1-11]. These studies have been on either vermicast generated from non-specific substrates in nature or from blends of soil and phytomass. The focus of the studies has been primarily on the stability of vermicast generated by anecic and endogeic (geophagous and 
geophytophagous) earthworm species as such casts are rich in soil and influence the stability of biogenic structures. Very few studies have been done on epigeic or phytophagous ('humus feeder') species. Moreover, when vermicast is deposited in nature, its fate is strongly influenced by (a) soil dwelling invertebrates-which colonize the vermicast and feed upon the organic matter it contains [5, 12]; (b) vegetation-which takes up the nutrients from the castings [13]; (c) soil microbes including autotrophic algae, nitrification bacteria or fungi-which are involved in fixation of atmospheric $\mathrm{CO}_{2}$ [13]; (d) immobilization or mineralization of nutrients in the vermicast by soil microorganisms [14], and (e) environmental factors such as rain, flooding, or drought.

A few controlled studies have been reported on the change in the properties of vermicast upon aging [1, 6, 1519]. These studies have primarily aimed to simulate the conditions which the biogenic structures experience in nature. For this, the casts were generated from either soil or blends of soil and phytomass and stored in soil/sand columns. It was seen that the soil particles present in the casts get chemically bound with organic matter, perhaps through chelation, which increases the stability of the casts. It also protects the organic matter content of the casts from decomposition [15, 20], as the organic matter that is attached to the minerals with strong chemical bounds is less accessible to microorganisms [21]. In addition, extracellular enzymes are protected from degradation or proteolysis by the clay minerals contributed by the soil [22].

In contrast to the focus of the prior art summarized as above, the conditions associated with the storage of vermicast when it is produced by anthropogenically controlled vermicomposting and for the specific purpose of use as a fertilizer are very different. The concern here is to ensure that the vermicast retains as many and as much of the plant-friendly attributes as does fresh vermicast and the physical integrity of the cast is not of much significance. The only pre-existing studies on the effect of storage on vermicompost [3, 4], have been based on the use of 2-month-old press-mud as feed for earthworms, and assessment of the changes in major nutrients ( $\mathrm{N}, \mathrm{P}$ and $\mathrm{K}$ ), microbial activity and enzyme activity of the vermicast that was generated. In these studies, the environmental conditions under which the casts have been exposed during the aging - either in vermireactors or in a controlled system-have not been defined. Also, the studies were done only at two stages - 15 th and 30th day of vermicast generation. Hence, no useful pointers can be drawn from these studies on the impact of storage.

The present study, which is perhaps the first of its kind, explores the changes in the physical, chemical and biological properties of vermicast that occur during storage with the objective of finding conditions that minimize the deterioration in the fertilizer value of the vermicast. The studies provide useful pointers on how best to store and package vermicast.

\section{Materials and methods}

Types of storage

The vermicompost used in the present work was generated from paper waste and the epigeic species, Eudrilus eugeniae. As paper waste is almost entirely cellulosic, with only traces of elements other than $\mathrm{C}, \mathrm{H}$, and $\mathrm{O}$, the feed was spiked with $9 \% \mathrm{w} / \mathrm{w}$ of cow dung to provide NPK and other nutrients in adequate amounts. The vermicomposting was accomplished with a high-rate process recently developed by the author's group [23]. The vermireactors were fabricated with aluminum sheets and each had a volume of $135 \mathrm{l}(15 \mathrm{~cm}$ height with surface area $150 \times 60 \mathrm{~cm})$. The vermicast was harvested after 30 days. One part of it was stored in two types of packs: (a) airtight sealed transparent polyethylene bags of $20 \mu \mathrm{m}$ thickness (AUD) and (b) partially sealed nylon mesh $(0.3 \mathrm{~mm})$ bags (PUD). Both types of bags were $25 \mathrm{~cm}$ long and $18 \mathrm{~cm}$ wide, each capable of holding half $\mathrm{kg}$ of vermicompost. Another part of the casts was pre-dried for $24 \mathrm{~h}$ at room temperature $\left(29 \pm 4{ }^{\circ} \mathrm{C}\right)$ and stored in both airtight sealed transparent polyethylene bags (APD) and partially sealed nylon mesh bags (PPD). In each set, 36 packs were utilized; overall 144 packs were studied. All storage was at room temperature $\left(29 \pm 4{ }^{\circ} \mathrm{C}\right)$ as this is the temperature at which vermicast is handled in the region where the authors work. Three packs of vermicast were taken once in a week for physical and biochemical analysis from each storage.

\section{Analysis}

Physical properties. To estimate bulk density, sample volume was measured with a graduated cylinder and its dry weight determined by oven drying [24].

- The particle density was determined by volumetric flask method [24]. The quotient value of weight of the sample and its volume which was measured through volume of water displaced by known amount of soil sample in the volumetric flask is reported as particle density.

- To measure the water holding capacity, the samples were filled in cylinders with a perforated base and immersed in water and drained. The quantity of water taken up by samples is determined by drying to constant mass at $105{ }^{\circ} \mathrm{C}$ [25].

- The total and water-filled porosity were calculated from the particle and bulk density values of the respective samples, using the following Eq. [26]. 
Total porosity $\left(S_{\mathrm{t}}\right)=1-\frac{D_{\mathrm{b}}}{D_{\mathrm{p}}}$

Air filled porosity $\left(F_{\mathrm{a}}\right)=\mathrm{S}_{\mathrm{t}}-\theta_{\mathrm{w}} D_{\mathrm{b}} / D_{\mathrm{w}}$

Water filled porosity $(\mathrm{WFPS})=\left(\mathrm{S}_{\mathrm{t}}-F_{\mathrm{a}}\right) / S_{\mathrm{t}}$

where, $D_{\mathrm{b}}$ is the bulk density, $D_{\mathrm{p}}$ is the particle density, $\theta_{\mathrm{w}}$ is gravimetric water content, and $D_{\mathrm{w}}$ is the density of water at corresponding temperature.

- Electrical conductivity (EC) and $\mathrm{pH}$ were measured with suspensions of samples in water $(1: 2, w / v)$ [24] using $\mathrm{EI}^{\mathrm{TM}}$ 611E EC meter and Digison ${ }^{\mathrm{TM}}$ digital $\mathrm{pH}$ meter 7007, respectively.

Chemical constituents. Total organic carbon $\left(\mathrm{C}_{\text {org }}\right)$ was determined following modified dichromate redox method [27]. External heating was applied during the oxidation process to quicken and complete oxidation of organic carbon in the sample.

- Dissolved organic carbon $\left(\mathrm{C}_{\mathrm{dis}}\right)$ was extracted in $0.5 \mathrm{M}$ $\mathrm{K}_{2} \mathrm{SO}_{4}$ solution $(1: 10$, w/v) and determined by the dichromate redox method [28].

- Total nitrogen $\left(\mathrm{N}_{\text {tot }}\right)$ was determined by modified Kjeldahl method [29] using Kel Plus ${ }^{\mathrm{TM}}$ semi-automated digester and distillation units. To include nitrate, nitrite, nitro and nitroso groups in the assay, a mixture of salicylic acid and sulfuric acid was used for digestion.

- Inorganic nitrogen was extracted with $2 \mathrm{M} \mathrm{KCl}$ solutions $(1: 10, \mathrm{w} / \mathrm{v})$ followed by determination of ammonium $\left(\mathrm{NH}_{4}{ }^{+}-\mathrm{N}\right)$ and nitrate $\left(\mathrm{NO}_{3}{ }^{-}-\mathrm{N}\right)$ in the suspensions by modified indophenol blue and Devarda's alloy methods, respectively [30].

- Extractable potassium $\left(\mathrm{K}_{\text {ext }}\right)$, calcium $\left(\mathrm{Ca}_{\text {ext }}\right)$ and sodium $\left(\mathrm{Na}_{\text {ext }}\right)$ were determined using a flame photometer (Elico ${ }^{\text {TM }}$ CL378) after extraction with neutral $1 \mathrm{~N}$ ammonium acetate solution.

- Extractable phosphorus $\left(\mathrm{P}_{\text {ext }}\right)$ was determined according to the ammonium molybdate-ascorbic acid method [31] after extracting with Mehlich 3 extraction solution $(1: 25, \mathrm{w} / \mathrm{v})$ [32].

- Mineral sulfur $\left(\mathrm{SO}_{4}{ }^{2-}-\mathrm{S}\right)$ was extracted with $0.0125 \mathrm{M}$ $\mathrm{CaCl}_{2}$ solution $(1: 4, \mathrm{w} / \mathrm{v})$, and determined by turbidimetric method described by Bashour and Sayegh [24].

Enzyme activity. Dehydrogenase enzyme activity (DHA) was estimated by determining the rate of reduction of iodonitro-tetrazolium chloride $(9.88 \mathrm{mM})$ to iodo-nitro-tetrazolium formazan, after incubation at $40{ }^{\circ} \mathrm{C}$ for $2 \mathrm{~h}$ [33].

- $\beta$-Glucosidase (BGA), alkaline phosphatase (APA) and arylsulphatase (ASA) enzyme activities were assayed by incubation of samples with $p$-nitrophenyl glucoside (0.025 M), p-nitrophenyl phosphate $(0.115 \mathrm{M})$ and p-nitrophenyl sulfate $(25 \mathrm{mM})$ as described by Eivazi and Tabatabai [34, 35] and Tabatabai and Bremner [36] followed by the spectrophotometric determination of the released $p$-nitrophenol.

- Cellulase (CEA) activity was assayed by determination of the reducing sugars released after incubation of samples with carboxymethyl cellulose sodium salt $(0.7 \%)$ for $24 \mathrm{~h}$ at $50{ }^{\circ} \mathrm{C}$, in a spectrophotometer at $690 \mathrm{~nm}$ [37].

- Urease (URA) activity was assessed by incubating samples with urea $(200 \mathrm{mM})$ for $2 \mathrm{~h}$ at $37^{\circ} \mathrm{C}$, and measuring the $\mathrm{NH}_{4}{ }^{+}$released in the hydrolysis reaction by steam distillation method using Kel Plus ${ }^{\mathrm{TM}}$ distillation unit [38].

- Microbial biomass carbon $\left(\mathrm{C}_{\text {mic }}\right)$ was determined by the chloroform fumigation-extraction method [28].

Processing of data

The experimental findings were statistically analyzed to assess whether different treatments exerted significant impact on the properties of vermicompost over the course of the storage. Pearson correlation was used to estimate the degree of association between each of the vermicast properties studied and their influence over others. Statistical significance is recognized at $P$ value $\leq 0.05$. The SPSS windows 16 package (Softonic, Barcelona, Spain) was used throughout.

\section{Results and discussion}

Physical properties

The physical properties of vermicast were significantly affected by pre-drying and storage (Table 1). Pre-drying reduced the moisture content, WHC, total porosity, and WFPS, while it increased the bulk and particle densities of the cast (Figs. 1, 2). In the course of 12 weeks, the moisture content of the cast of PUD and PPD treatments was reduced by $69.4 \pm 0.1$ and $62.1 \pm 0.6 \%$, and those of the AUD and APD by $5.7 \pm 0.8$ and $7.6 \pm 0.6 \%$, respectively. The bulk density increased in the PUD and PPD storage to the extent of $49.7 \pm 0.8$ and $45.8 \pm 1.7 \%$ and in AUD and APD to the extent of $21.8 \pm 2.0$ and $29.1 \pm 0.3 \%$, respectively. Structural compactness occurring due to water loss in drying may be the reason for the greater increase in the bulk density in the PUD and PPD storage. The WHC also reduced drastically due to this reason in both PUD and PPD storage. It was reduced by about $50 \%$ in PUD and PPD storage, in comparison to $14.1 \pm 0.3$ and $19.2 \pm 1.2 \%$, respectively, in the AUD 
Table $1 F$ values of repeated measures analysis of variance on the effect of extent of sealing and pre-treatment on physical properties, EC and $\mathrm{pH}$ of vermicast during the storage

\begin{tabular}{|c|c|c|c|c|c|c|c|c|}
\hline Treatment & $\begin{array}{l}\text { Moisture } \\
\text { content }\end{array}$ & $\begin{array}{l}\text { Bulk } \\
\text { density }\end{array}$ & $\begin{array}{l}\text { Particle } \\
\text { density }\end{array}$ & $\begin{array}{l}\text { Water holding } \\
\text { capacity }\end{array}$ & $\begin{array}{l}\text { Total } \\
\text { porosity }\end{array}$ & $\begin{array}{l}\text { Water-filled pore } \\
\text { space }\end{array}$ & $\mathrm{EC}$ & $\mathrm{pH}$ \\
\hline Extend of sealing & $5,676.8^{* * * *}$ & $6,641.1^{* * * *}$ & $113.8^{* * * *}$ & $886.9^{* * * *}$ & $1,781.0^{* * * *}$ & $7.738^{*}$ & $5.290^{\text {n.s }}$ & $4.503^{\text {n.s }}$ \\
\hline Pre-treatment & $63,025.5^{* * *}$ & $58,466.9^{* * *}$ & $395.8^{* * * *}$ & $8,369.3^{* * * *}$ & $17,477.4^{* * * *}$ & $6,425.2^{* * *}$ & $2,097.3^{* * *}$ & $0.318^{\text {n.s }}$ \\
\hline $\begin{array}{l}\text { Extend of sealing X pre- } \\
\text { treatment }\end{array}$ & $1,627.7^{* * *}$ & $4,155.3^{* * *}$ & $6.362^{*}$ & $200.0^{* * * *}$ & $1,932.8^{* * *}$ & $329.73^{* * * *}$ & $3.116^{\text {n.s }}$ & $15.17^{*}$ \\
\hline
\end{tabular}

* $P<0.05,{ }^{* *} P<0.01,{ }^{* * * *} P<0.001,{ }^{\text {n.s }}$ not significant

Fig. 1 Changes in the moisture content (a), bulk density (b), particle density (c) and water holding capacity (d) of undried and pre-dried castings stored in airtight sealed bags (AUD and APD, respectively) and undried and pre-dried castings stored in partially sealed bags (PUD and PPD, respectively), at different periods of time
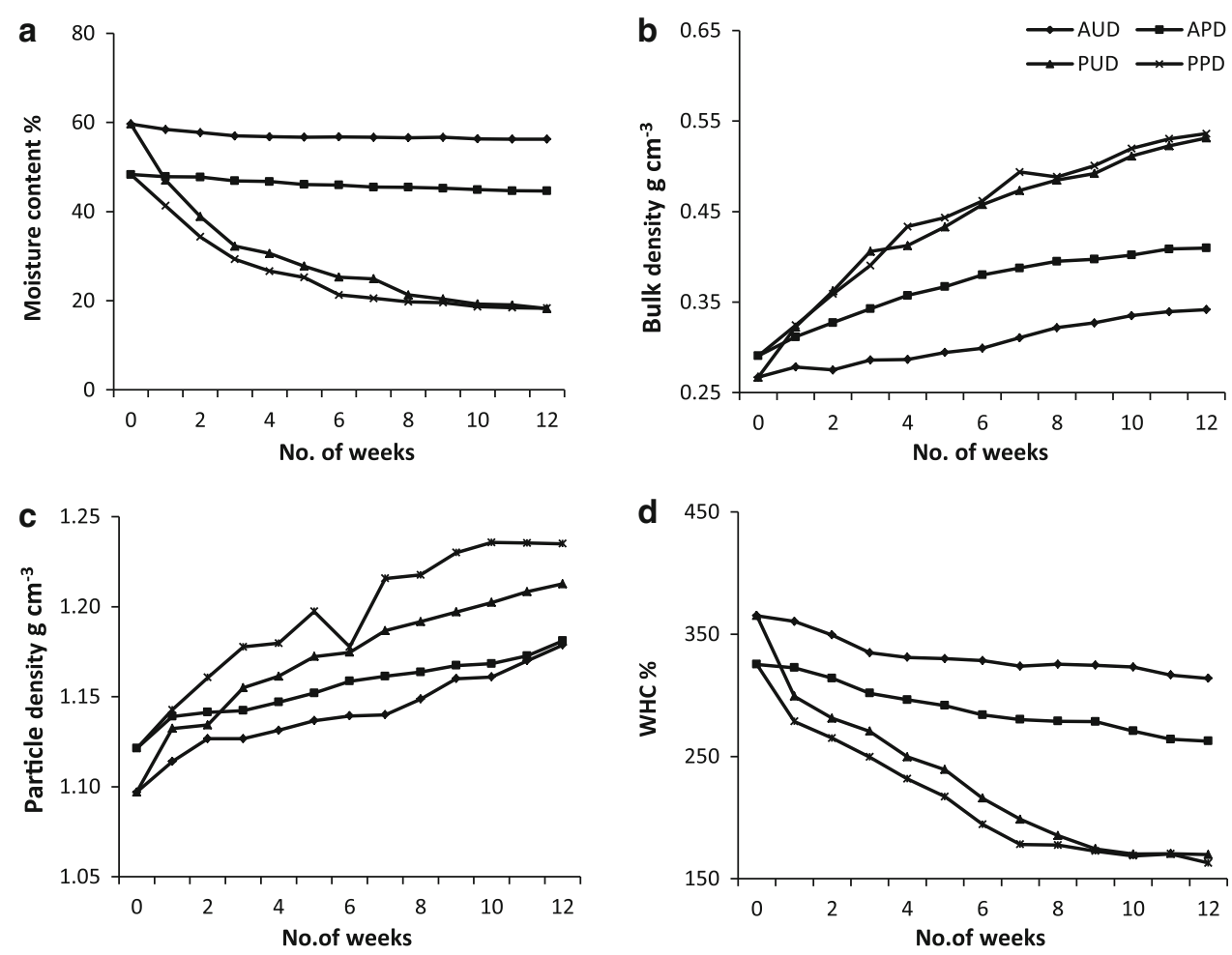

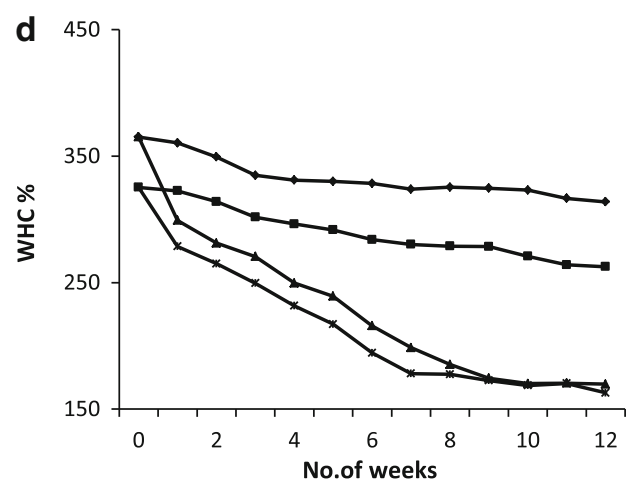

and APD storage. A significant linear relationship $(P<0.001)$ was found between WHC and porosity of castings. At the end of the experiments, the cast in the PUD and PPD storage showed about $25 \%$ reduction in the total porosity and those in the AUD and APD about 6 and $12 \%$ reduction, respectively. Hydrophilic components of organic matter, such as polysaccharides, might also have influenced the WHC of castings [39].

The WFPS values increased to the extent of $22.4 \pm 3.4$ and $32.7 \pm 0.5 \%$ in AUD and APD storage and decreased by $18.4 \pm 2.0$ and $8.5 \pm 5.8 \%$ in the PUD and PPD storage, respectively. Reduction in structural pores during dehydration and decomposition of organic matter may be the reason for lower WFPS of the PUD and PPD storage [40, 41]. The changes in the WFPS of vermicast may have a distinct impact on the regulation of hydrological properties, gas diffusion, microbial colonization, nutrient mineralization etc. [42-44].
The particle density of cast showed an increasing trend in all the storage and the maximum of about $9 \%$ increase was observed in the PUD and PPD. The rate of increase in particle density of casts indicates the degree of decomposition of organic matter they contain [45, 46]. Increasing trend was also observed with EC, in which maximum increase of $33.5 \pm 0.1$ and $27.1 \pm 2.6 \%$ was in AUD and APD storage and $15.5 \pm 1.0$ and $6.8 \pm 3.4 \%$, respectively, in PUD and PPD. The castings in all types of storage had $\mathrm{pH}$ close to neutral all the time (6.99-7.21); minor fluctuations occurred due to the production of organic acids and the release of $\mathrm{CO}_{2}$ during the microbial decomposition of organic matter [47, 48].

\section{Chemical properties}

The chemical properties of cast were significantly influenced by pre-drying and storage $(P<0.001)$ (Table 2$)$. 
Fig. 2 Changes in the total porosity (a), water-filled porosity (b), $\mathrm{pH}(\mathbf{c})$ and $\mathrm{EC}$ (d) of undried and pre-dried castings stored in airtight sealed bags (AUD and APD, respectively) and undried and pre-dried castings stored in partially sealed bags (PUD and PPD, respectively), at different periods of time
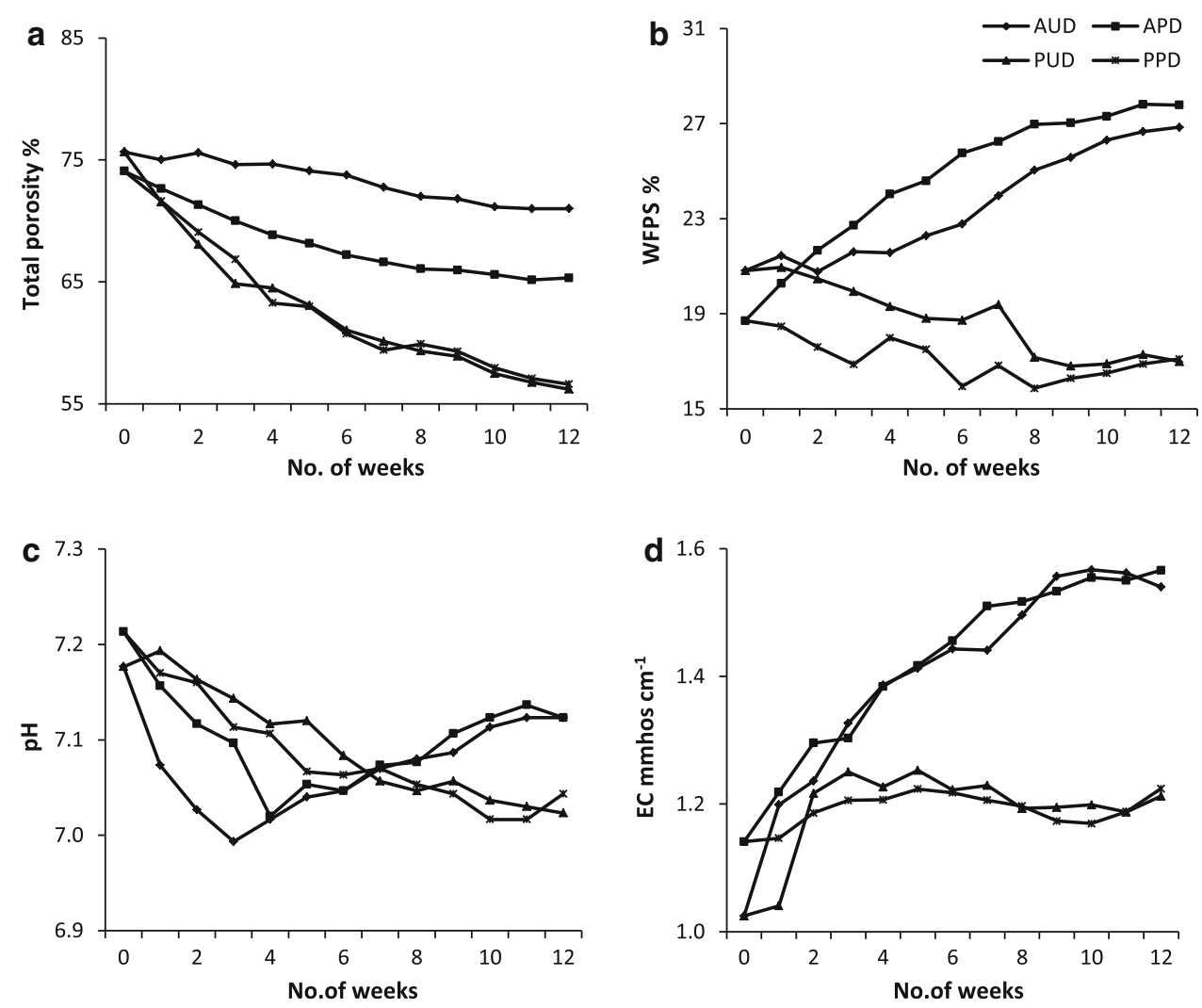

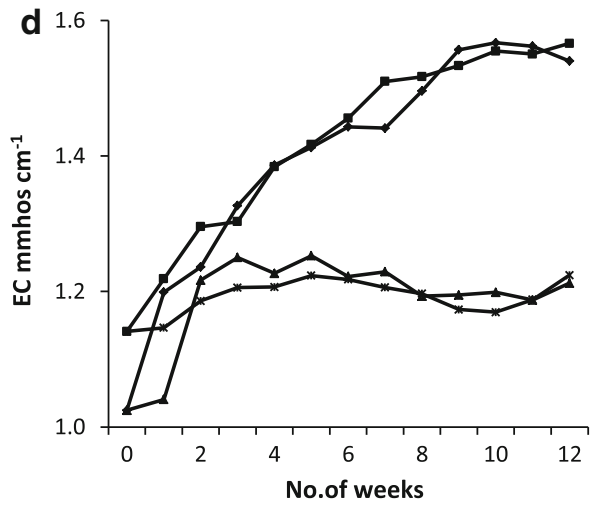

Pre-drying reduced the $\mathrm{C}_{\text {org }}, \mathrm{C}_{\mathrm{dis}}, \mathrm{N}_{\text {tot }}, \mathrm{NH}_{4}{ }^{+}-\mathrm{N}$ and $\mathrm{P}_{\text {ext }}$ and increased the $\mathrm{NO}_{3}{ }^{-}-\mathrm{N}, \mathrm{K}_{\text {ext }}, \mathrm{SO}_{4}{ }^{2-}-\mathrm{S}, \mathrm{Ca}_{\text {ext }}$ and $\mathrm{Na}_{\text {ext }}$ content of the cast significantly. The PUD and PPD storage showed higher reduction in $\mathrm{C}_{\mathrm{org}}, \mathrm{C}_{\mathrm{dis}}, \mathrm{N}_{\text {tot }}, \mathrm{P}_{\text {ext }}$ and $\mathrm{K}_{\text {ext }}$ than the AUD and APD storage (Figs. 3, 4). In the case of $\mathrm{C}_{\text {org }}$, about $8 \%$ reduction was observed with PUD and PPD storage and less than $1.5 \%$ in AUD and APD. The higher reduction of $\mathrm{C}_{\mathrm{org}}$ in the PUD and PPD, which was maximum in the first 2 weeks, was probably due to rapid mineralization of $\mathrm{C}$ by aerobic microbes [49]. A few past studies on the aging of cast of anecics and endogeics have also reported high $\mathrm{C}$ mineralization in the initial period [7, $50,51]$. The reduction in WFPS with time may be influencing the extent of $\mathrm{C}$ mineralization as the days progressed because reduction in the water-filled pores during the storage might be curtailing the microbial access to the substrate [42, 52]. The cast in the PUD and PPD storage also showed a maximum reduction in $\mathrm{C}_{\mathrm{dis}}$ content: more than $90 \%$ in comparison to $71.7 \pm 0.6$ and $88.0 \pm 0.3 \%$, respectively, in the AUD and APD storage. Low C utilizing efficiency of anaerobic microbial community, which is expected to dominate in the AUD and APD storage could be the reason for the lesser reduction of $\mathrm{C}_{\mathrm{dis}}$ content in these types of storage [53, 54].

The $\mathrm{N}_{\text {tot }}$ content of the cast reduced to the extent of $66.9 \pm 0.5$ and $54.6 \pm 0.3 \%$ in the PUD and PPD storage, respectively. There was about $30 \%$ reduction in the $\mathrm{N}_{\text {tot }}$ during the first week, probably due to intense ammonia volatilization. The high $\mathrm{NH}_{4}{ }^{+}-\mathrm{N}$ content of fresh castings also supports this assumption. As the number of days progressed, the ammonium content of the casts in the PUD and PPD storage reduced up to $83 \%$ due to the intense nitrification and ammonia volatilization from the existing ammonium pools. There was a concomitant increase in nitrate content of the cast over time: $72.2 \pm 0.3$ and $60.0 \pm 2.0 \%$ with the PUD and PPD storage, respectively, by the end of the study. Previous studies on cast aging have also reported rapid exhaustion of most of the ammonium present in the castings $[8,55,56]$. In contrast, the cast of AUD and APD storage showed reduction in both $\mathrm{NH}_{4}{ }^{+}-\mathrm{N}$ and $\mathrm{NO}_{3}{ }^{-}-\mathrm{N}$. Anoxic condition created in AUD and APD storage due to the airtight sealing might have impeded the nitrification process $[57,58]$, even as the slow reduction in the mineral nitrogen content of the casts may be due to microbial immobilization [2, 59].

In all cases, the $\mathrm{P}_{\text {ext }}$ in cast increased during the initial week and further storage showed a steady decline till the end. The high availability of carbon and nitrogen in fresh cast would have increased the phosphorus demand and it probably enhanced phosphatase activity resulting in increased $\mathrm{P}_{\mathrm{ext}}$ during the initial week [3, 60]. As the number of days progressed, the $\mathrm{P}_{\mathrm{ext}}$ in the PUD and PPD storage reduced by $71.5 \pm 0.3$ and $73.9 \pm 1.5 \%$. In AUD and APD, it was reduced by $68.0 \pm 1.2$ and $61.9 \pm 1.6 \%$, 


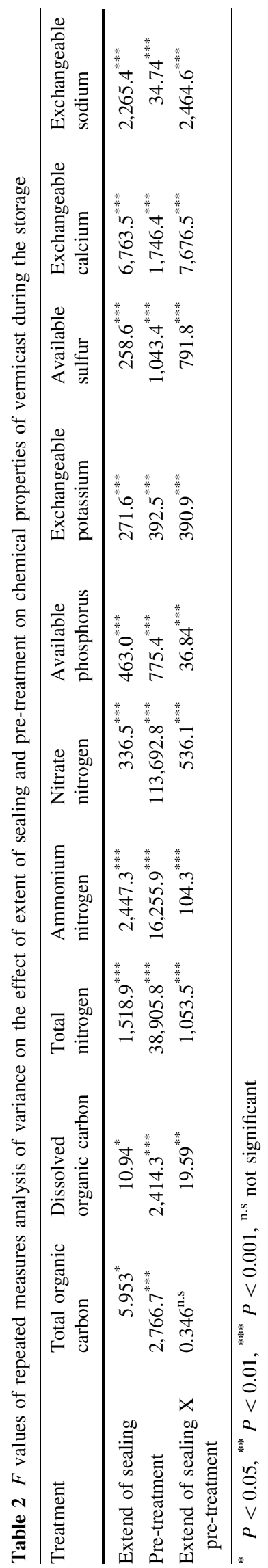

respectively. The $\mathrm{K}_{\mathrm{ext}}$ in the casts also increased in the initial week, but further storage reduced it in all the treatments. This was particularly pronounced in the PUD and PPD when the reduction in $\mathrm{K}_{\text {ext }}$ was $16.2 \pm 2.1$ and $27.5 \pm 1.6 \%$; in comparison to $5.4 \pm 2.0$ and $1.6 \pm 2.3 \%$ in AUD and APD, respectively. Similarly, the $\mathrm{SO}_{4}{ }^{2-}-\mathrm{S}$ content of the cast showed about $20 \%$ increase during the initial week, while further storage decreased it. The increase in the $\mathrm{C} / \mathrm{S}$ ratio of the cast to above 600 that occurred during this period may be attributed to high immobilization of available sulfur [61, 62]. Throughout the experiment, the $\mathrm{Ca}_{\mathrm{ext}}$ in the cast fluctuated in the AUD and APD storage. Increased solubility of organic carbon and increased competition between the cations for the negatively charged sites due to increased levels of $\mathrm{Fe}$ and $\mathrm{Mn}$ under reducing conditions may be the reasons for this fluctuation [63, 64]. The $\mathrm{Ca}_{\text {ext }}$ in cast of PUD and PPD storage steadily declined till the end, while $\mathrm{Na}_{\text {ext }}$ declined to the extent of $11.1 \pm 0.8$ and $31.1 \pm 0.1 \%$ in the PUD and PPD storage and $19.0 \pm 0.6$ and $23.2 \pm 0.5 \%$, respectively, in AUD and APD.

\section{Biochemical properties}

Pre-drying of the casts had strong influence on the enzyme activities (Table 3). Except URA, the activities of all other enzymes assayed-DHA, CEA, BGA, APA and ASAinitially increased in the pre-dried cast before declining. The extent of this change varied with the type of storage (Fig. 5). As much as 82 and $77 \%$ increase in DHA was recorded in the first few weeks of AUD and APD storage, but further storage reduced the DHA activity to only $20.9 \pm 4.4$ and $5.0 \pm 4.0 \%$, respectively. In the case of PUD and PPD storage, DHA activity increased during the first week, and then declined to the extent of $89.0 \pm 0.3$ and $97.6 \pm 0.2 \%$, respectively. This trend may be due to enhanced growth of facultative anaerobic microorganisms caused by exhaustion of oxygen in these types of storage $[65,66]$. Further storage reduced the DHA activity, possibly due to subsequent decline in the availability of nutrients.

The BGA activity of the casts increased to about $73 \%$ in the PUD and PPD storage by the second week. Then, there was a steady decline till it fell to $48.8 \pm 0.2$ and $49.5 \pm 1.2 \%$, respectively, at the end. Similar trend was observed with AUD and APD storage, in which there was about $67 \%$ increase in BGA activity during the second week, and $62.4 \pm 1.0$ and $69.0 \pm 0.6 \%$ reduction by the twelfth week. The CEA activity of castings also increased with PUD, PPD and APD storage during the initial week, but then fell as much as sevenfold; those of AUD reduced ninefold. During the initial week, more than four times increase in APA activity was observed with the PUD and 
Fig. 3 Changes in the total organic carbon (a), dissolved organic carbon (b), total nitrogen (c), ammonium nitrogen (d), nitrate nitrogen (e) and available phosphorus (f) content of undried and predried castings stored in airtight sealed bags (AUD and APD, respectively) and undried and pre-dried castings stored in partially sealed bags (PUD and PPD, respectively), at different periods of time
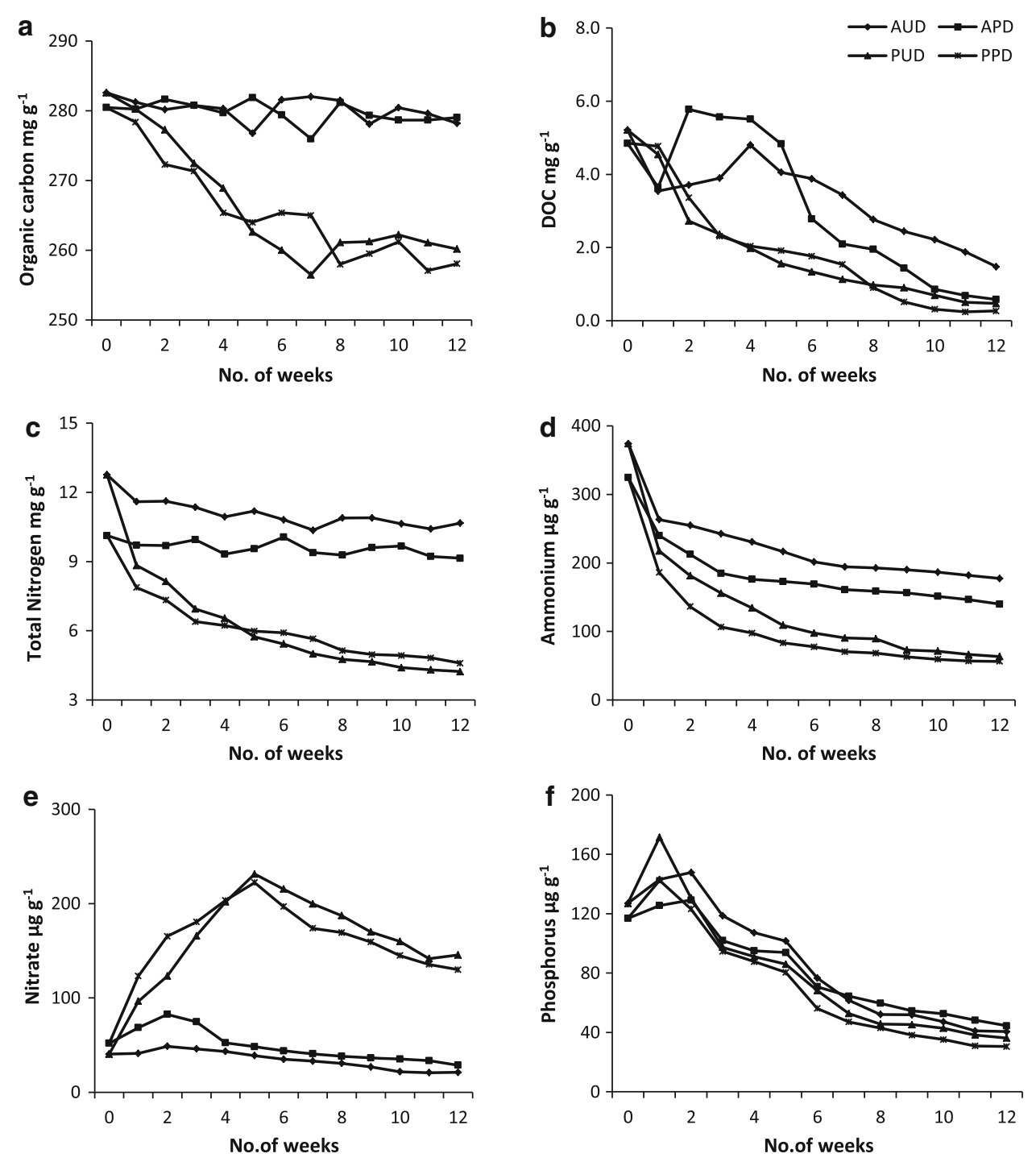

PPD storage, and about twice with AUD and APD. Further storage reduced the APA activity in all the cases. In the AUD and APD storage, the reduction in APA activity was $40.8 \pm 1.1$ and $47.1 \pm 1.2 \%$ and in PUD and PPD storage it was $61.3 \pm 1.0$ and $71.4 \pm 1.9 \%$, respectively.

During the first week, there was a slight increase in ASA activity with AUD and APD storage. In the case of PUD and PPD storage, the ASA activity increased up to third and fourth weeks, respectively. Further storage showed a drastic reduction in the ASA activity with all types of storage: $\quad 93.3 \pm 0.4, \quad 96.8 \pm 0.3, \quad 97.9 \pm 0.2, \quad$ and $99.4 \pm 0.1 \%$, in AUD, APD, PUD and PPD, respectively. Fresh casts had the highest URA activity, which was reduced to $83.1 \pm 1.0, \quad 89.7 \pm 0.3, \quad 95.1 \pm 0.3$, and $94.8 \pm 0.3 \%$ in AUD, APD, PUD and PPD, respectively, at the end.

In summary, except URA, the activities of all other enzymes first rose in the initial weeks possibly due to high availability of nutrients and physical conditions favorable for aerobic microbial growth [67]. Subsequent decline in the nutrient content [68,69], moisture content [70] and availability of oxygen [71, 72] with different types of storage may have contributed to the subsequent decline in the enzyme activities.

Pre-drying increased the $\mathrm{C}_{\text {mic }}$ content of the casts significantly; it was $16.5 \pm 0.7 \%$ higher than the fresh ones (Fig. 6). During the first week, $\mathrm{C}_{\mathrm{mic}}$ increased to $20 \%$ in the PUD and PPD storage, probably due to the high availability of nutrients which might have promoted high microbial activity during this period. Further storage led to reduction across the board: $70.0 \pm 0.6, \quad 78.2 \pm 0.7$, $93.8 \pm 0.6,96.3 \pm 0.2 \%$, in AUD, APD, PUD, and PPD storage, respectively. Subsequent decline in the availability of nutrients and the moisture content in PUD and PPD storage may probably be the reason for the decline in $\mathrm{C}_{\text {mic }}$. In the case of AUD and APD, the reduction in $\mathrm{C}_{\text {mic }}$ may be 
Fig. 4 Changes in the extractable potassium (a), sulfur (b), calcium (c) and sodium (d) content of undried and predried castings stored in airtight sealed bags (AUD and APD, respectively) and undried and pre-dried castings stored in partially sealed bags (PUD and PPD, respectively), at different periods of time
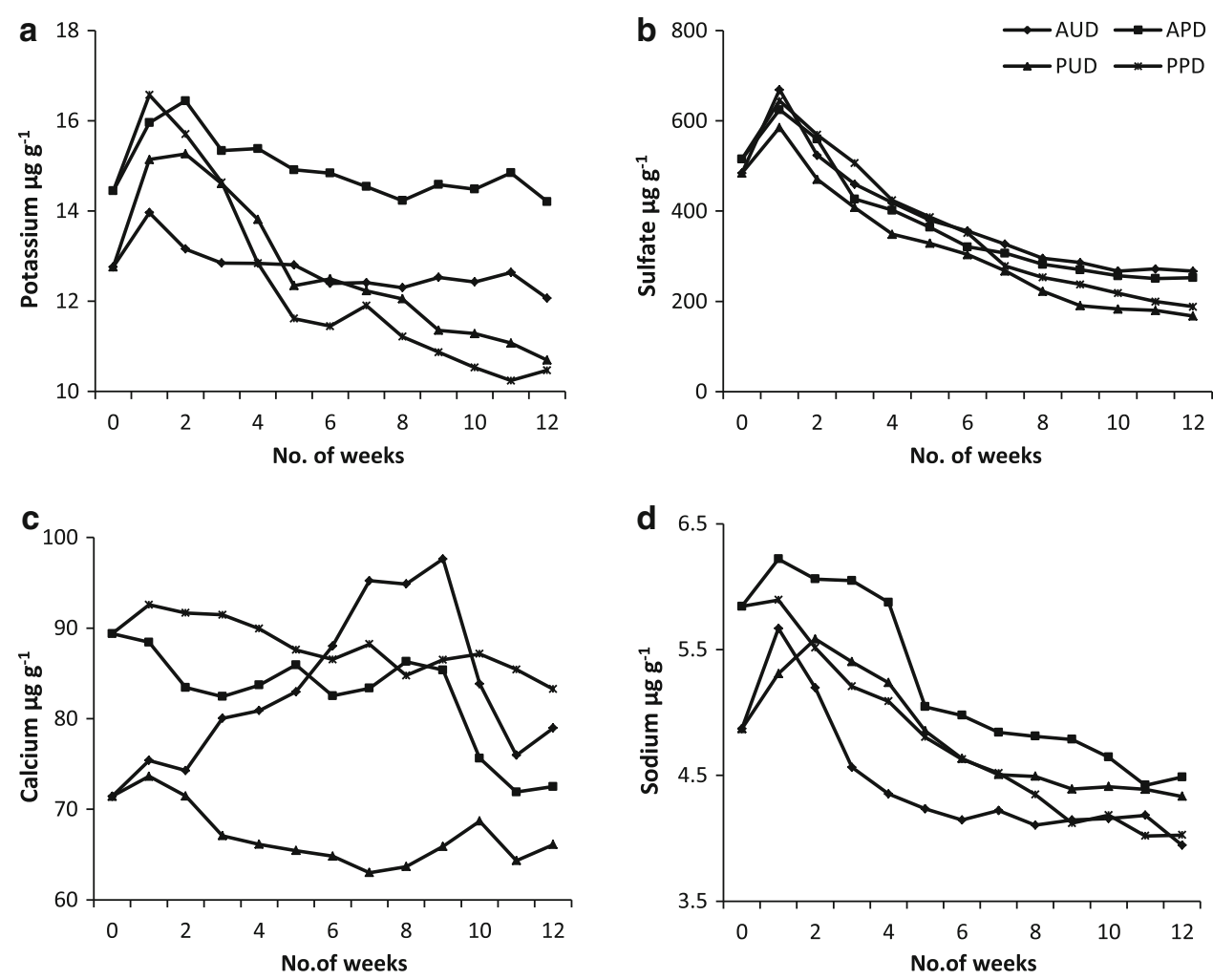

Table $3 F$ values of repeated measures analysis of variance on the effect of extent of sealing and pre-treatment on biochemical properties of vermicast during the storage

\begin{tabular}{|c|c|c|c|c|c|c|c|}
\hline Treatment & $\begin{array}{l}\text { Dehydrogenase } \\
\text { activity }\end{array}$ & $\begin{array}{l}\text { Cellulase } \\
\text { activity }\end{array}$ & $\begin{array}{l}\beta \text {-Glucosidase } \\
\text { activity }\end{array}$ & $\begin{array}{l}\text { Urease } \\
\text { activity }\end{array}$ & $\begin{array}{l}\text { Alkaline } \\
\text { phosphatase } \\
\text { activity }\end{array}$ & $\begin{array}{l}\text { Arylsulphatase } \\
\text { activity }\end{array}$ & $\begin{array}{l}\text { Microbial } \\
\text { biomass carbon }\end{array}$ \\
\hline Extend of sealing & $54.07^{* * *}$ & $19,418.5^{* * * *}$ & $1,393.6^{* * * *}$ & $11,285.5^{* * * *}$ & $4,538.0^{* * *}$ & $2,654.1^{* * * *}$ & $1,876.5^{* * *}$ \\
\hline Pre-treatment & $98,894.9^{* * * *}$ & $13.06^{* *}$ & $12,427.8^{* * * *}$ & $4,375.5^{* * *}$ & $5,307.3^{* * *}$ & $65,483.6^{* * * *}$ & $4,852.6^{* * *}$ \\
\hline $\begin{array}{l}\text { Extend of sealing } \mathrm{X} \\
\text { pre-treatment }\end{array}$ & $544.3^{* * *}$ & $11,275.7^{* * * *}$ & $281.3^{\text {**** }}$ & $3,477.9^{* * * *}$ & $3,957.7^{* * *}$ & $760.1^{\text {**** }}$ & $4.894^{\mathrm{n} . \mathrm{s}}$ \\
\hline
\end{tabular}

* $P<0.05,{ }^{* *} P<0.01,{ }^{* * * *} P<0.001,{ }^{\text {n.s }}$ not significant

attributed to the shift of aerobic microbial groups to anaerobes due to induced anoxic condition and which has very low $\mathrm{C}$ utilizing efficiency than the former [54].

Summary and conclusion

A 3-month-long study has been described on the effect of storage on the fertilizer value of vermicast. In what is arguably the first study of its kind, several physical, chemical, and biological attributes of the vermicast as stored with or without pre-drying, and with or without airtight containment, were assayed at 7-day intervals. The manner of storage was seen to influence the plant-friendly attributes of vermicast in a strong fashion. Airtight storage after pre-drying was the most beneficial, followed by airtight storage of the fresh, undried, vermicast. In partially sealed storage, there was significantly more rapid deterioration of the beneficial attributes than in airtight storage. Interestingly, whereas 24-h pre-drying before airtight storage was helpful in retaining the plant-friendly attributes of the vermicast for longer than fresh-airtight storage, predrying before partially sealed storage had the opposite effect. Apparently, partially sealed storage added to the water loss that had already occurred during the pre-drying, and brought the water content below a level that was needed to support biological activity within the vermicast matrix. This indicates that a certain level of water content is most appropriate for retaining the microbiological and enzyme activities of the vermicast; and the presence of water above or below that level hastens the cast's aging. Further work should be aimed at determining the most beneficial water levels and how best to retain them. 
Fig. 5 Changes in the dehydrogenase (a), $\beta$ glucosidase (b), cellulase (c), urease (d), alkaline phosphatase (e) and arylsulphatase (f) enzymes activity of undried and pre-dried castings stored in airtight sealed bags (AUD and APD, respectively) and undried and pre-dried castings stored in partially sealed bags (PUD and PPD, respectively), at different periods of time
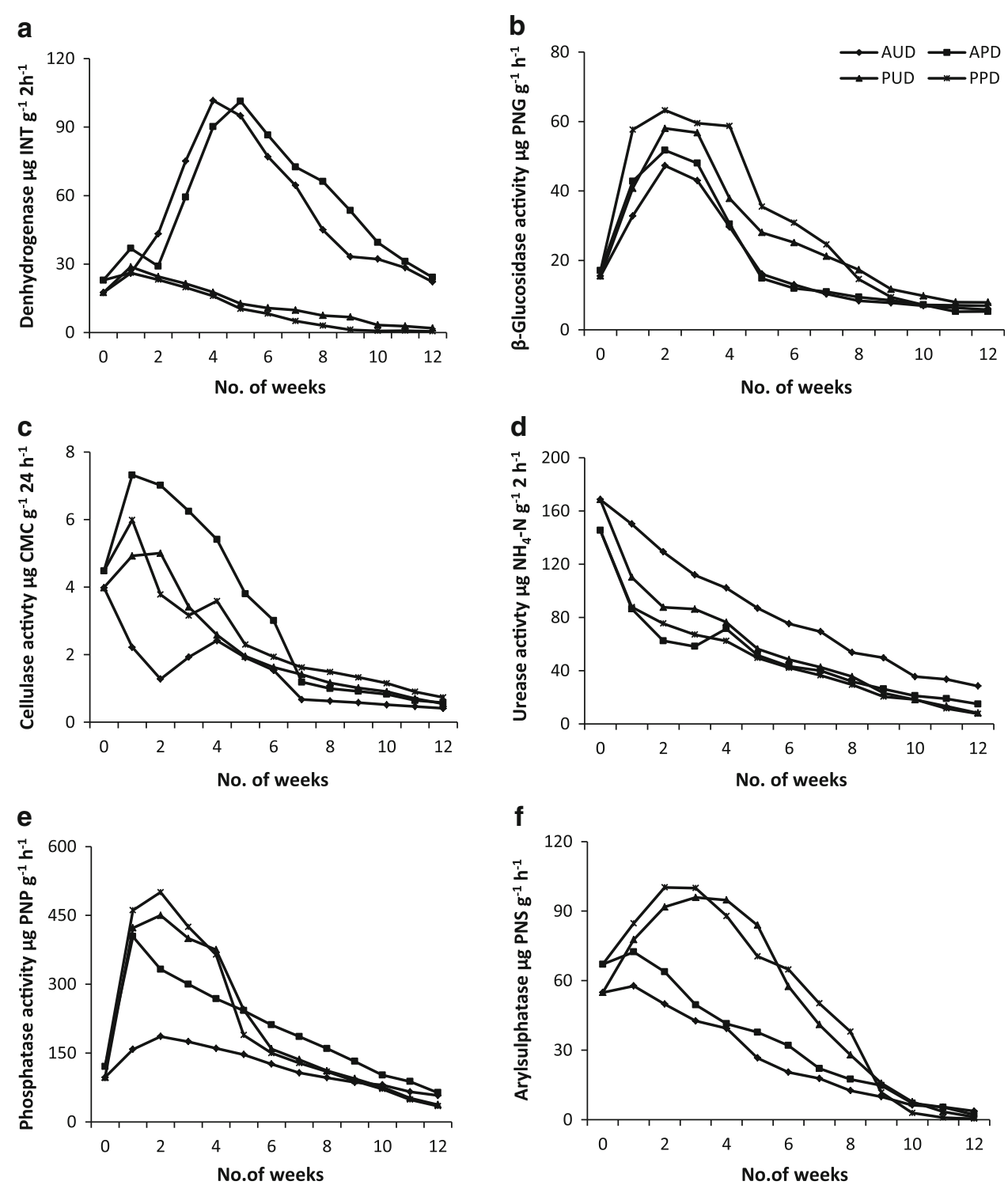

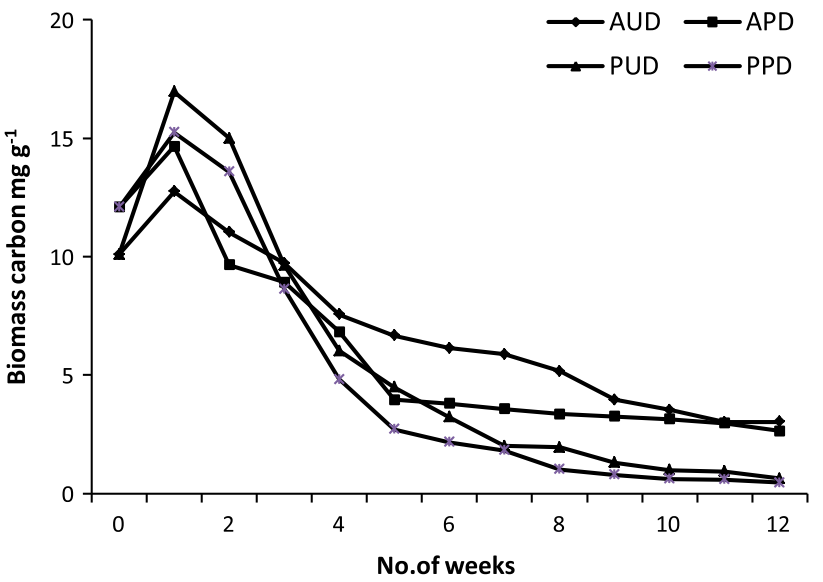

Fig. 6 Changes in the microbial biomass carbon content of undried and pre-dried castings stored in airtight sealed bags (AUD and APD, respectively) and undried and pre-dried castings stored in partially sealed bags (PUD and PPD, respectively), at different periods of time
Acknowledgments MK thanks the University Grants Commission, New Delhi for the research fellowship under the Rajiv Gandhi National Fellowship scheme.

Open Access This article is distributed under the terms of the Creative Commons Attribution License which permits any use, distribution, and reproduction in any medium, provided the original author(s) and the source are credited.

\section{References}

1. Hindell, R.P., McKenzie, B.M., Tisdall, J.M.: Influence of drying and ageing on the stabilization of earthworm (Lumbricidae) casts. Biol. Fertil. Soils 25, 27-35 (1997)

2. Decaëns, T., Rangel, A.F., Asakawa, N., Thomas, R.J.: Carbon and nitrogen dynamics in ageing earthworm casts in grasslands of the eastern plains of Colombia. Biol. Fertil. Soils 30, 20-28 (1999)

3. Parthasarathi, K., Ranganathan, L.S.: Longevity of microbial and enzyme activity and their influence on NPK content in pressmud vermicasts. Eur. J. Soil Biol. 35, 107-113 (1999) 
4. Parthasarathi, K., Ranganathan, L.S.: Aging effect on enzyme activities in pressmud vermicasts of Lampito mauritii (Kinberg) and Eudrilus eugeniae (Kinberg). Biol. Fertil. Soils 30, 347-350 (2000)

5. Decaëns, T.: Degradation dynamics of surface earthworm casts in grasslands of the eastern plains of Colombia. Biol. Fertil. Soils 32, 149-156 (2000)

6. Tiunov, A.V., Scheu, S.: Microbial biomass, biovolume and respiration in Lumbricus terrestris L. cast material of different age. Soil Biol. Biochem. 32, 265-275 (2000)

7. Scullion, J., Goodacre, R., Elliott, G., Huang, W., Worgan, H., Jones, D.G., Griffith, G., Darby, R., Bailey, M., Clegg, C., Draper, J.: Food quality and microbial succession in ageing earthworm casts: standard microbial indices and metabolic fingerprinting. Pedobiologia 47, 888-894 (2003)

8. Aira, M., Monroy, F., Dominguez, J.: Ageing effects on nitrogen dynamics and enzyme activities in casts of Aporrectodea caliginosa (Lumbricidae). Pedobiologia 49, 467-473 (2005)

9. Aira, M., Lazcano, C., Brandón, M.G., Domínguez, J.: Ageing effects of casts of Aporrectodea caliginosa on soil microbial community structure and activity. Appl. Soil Ecol. 46, 143-146 (2010)

10. Mariani, L., Jimenez, J.J., Asakawa, N., Thomas, R.J., Decaens, T.: What happens to earthworm casts in the soil? A field study of carbon and nitrogen dynamics in Neotropical savannahs. Soil Biol. Biochem. 39, 757-767 (2007)

11. Kawaguchi, T., Kyoshima, T., Kaneko, N.: Mineral nitrogen dynamics in the casts of epigeic earthworms (Metaphire hilgendorf: Megascolecidae). Soil Sci. Plant Nutr. 57, 387-395 (2011)

12. Decaens, T., Mariani, L., Lavelle, P.: Soil surface macrofaunal communities associated with earthworm casts in grasslands of the Eastern Plains of Colombia. Appl. Soil Ecol. 13, 87-100 (1999)

13. Jiménez, J.J., Decaëns, T.: The impact of soil organisms on soil functioning under neotropical pastures: a case study of a tropical anecic earthworm species. Agric. Ecosyst. Environ. 103, 329-342 (2004)

14. Kharin, S.A., Kurakov, A.V.: Transformation of nitrogen compounds and dynamics of microbial biomass in fresh casts of Aporrectodea caliginosa. Eurasian Soil Sci. 42, 75-81 (2009)

15. Shipitalo, M.J., Protz, R.: Chemistry and micromorphology of aggregation in earthworm casts. Geoderma 45, 357-374 (1989)

16. Marinissen, J.C.Y., Dexter, A.R.: Mechanisms of stabilization of earthworm casts and artificial casts. Biol. Fertil. Soils 9, 163-167 (1990)

17. Marinissen, J.C.Y., Nijhuis, E., Breemen, V.: Clay dispersability in moist earthworm casts of different soils. Appl. Soil Ecol. 4, 83-92 (1996)

18. Hindell, R.P., McKenzie, B.M., Tisdall, J.M.: Destabilization of soil during the production of earthworm (Lumbricidae) and artificial casts. Biol. Fertil. Soils 24, 153-163 (1997)

19. McInerney, M., Bolger, T.: Temperature, wetting cycles and soil texture effects on carbon and nitrogen dynamics in stabilized earthworm casts. Soil Biol. Biochem. 32, 335-349 (2000)

20. McInerney, M., Little, D.J., Bolger, T.: Effect of earthworm cast formation on the stabilization of organic matter in fine soil fractions. Eur. J. Soil Biol. 37, 251-254 (2001)

21. Kaiser, K., Mikutta, R., Guggenberger, G.: Increased stability of organic matter sorbed to ferrihydrite and goethite on aging. Soil Sci. Soc. Am. J. 71, 711-719 (2007)

22. Nannipieri, P., Smalla, K.: Nucleic acids and proteins in soil. Springer, Berlin (2006)

23. Gajalakshmi, S., Makhija, M., Abbasi, S.A.: A pre-pilot benchbench study on vermicomposting of paper waste. In: Abstracts of the National Seminar on Energy Resources, Energy Impact and Industrial Waste Management (EEIWM), Department of Environmental Science, Sri Venketeswara University, Tirupati, 27-28 February 2012
24. Bashour, I., Sayegh, H.A.: Methods of analysis for soils of arid and semi-arid regions. Food and Agriculture Organization of the United Nations, Rome (2007)

25. Margesin, R., Schinner, F.: Manual for soil analysis-monitoring and assessing soil bioremediation. Springer, Berlin (2005)

26. Carter, M.R., Gregorich, E.G.: Soil sampling and methods of analysis, 2nd edn. Canadian Society of Soil Science. Taylor and Francis Group, LLC (2008)

27. Heanes, D.L.: Determination of total organic-C in soils by an improved chromic acid digestion and spectrophotometric procedure. Commun. Soil Sci. Plant Anal. 15, 1191-1213 (1984)

28. Jenkinson, D.S., Brookes, P.C., Powlson, D.S.: Measuring soil microbial biomass. Soil Biol. Biochem. 36, 5-7 (2004)

29. Kandeler, E.: Bestimung von Gesamtstickstoff nach kjeldahl. In: Schinner, F., Kandeler, E., Ohlinger, R., Margesin, R. (eds.) Bodenbiologische Arbeitsmethoden, pp. 346-366. Springer, Berlin (1993)

30. Jones, J.B.: Laboratory guide for conducting soil tests and plant analysis. CRC Press, New York (2001)

31. Knudsen, D., Beegle, D.: Recommended phosphorus tests. In: Dahnke, W.C. (eds) Recommended chemical soil tests procedures for the North Central region, pp. 12-15. Bulletin No. 499 (Revised), North Dakota Agricultural Experiment Station, Fargo, North Dakota (1988)

32. Mehlich, A.: Mehlich 3 soil test extractant: a modification of the Mehlich 2 extractant. Commun. Soil Sci. Plant Anal. 15, 1409-1416 (1984)

33. Mersi, W., Sehinner, F.: An improved and accurate method for determining the dehydrogenase activity of soils with iodo-nitrotetrazolium chloride. Biol. Fertil. Soils 11, 216-220 (1991)

34. Eivazi, F., Tabatabai, M.A.: Phosphatases in soils. Soil Biol. Biochem. 9, 167-172 (1977)

35. Eivazi, F., Tabatabai, M.A.: Glucosidases and galactosidases in soils. Soil Biol. Biochem. 20, 601-606 (1988)

36. Tabatabai, M.A., Bremner, J.M.: Arylsulfatase activity of soil. Soil Sci. Soc. Am. Proc. 34, 225-229 (1970)

37. Schinner, F., von Mersi, W.: Xylanase, CM-cellulase and invertase activity in soil: an improved method. Soil Biol. Biochem. 22, 511-515 (1990)

38. Tabatabai, M.A., Bremner, J.M.: Assay of urease activity in soils. Soil Biol. Biochem. 4, 479-487 (1972)

39. Li, X.G., Li, F.M., Zed, R., Zhan, Z.Y., Singh, B.: Soil physical properties and their relations to organic carbon pools as affected by land use in an alpine pastureland. Geoderma 139, 98-105 (2007)

40. Schwärzel, K., Renger, M., Sauerbrey, R., Wessolek, G.: Soil physical characteristics of peat soils. J. Plant Nutr. Soil Sci. 165, 479-486 (2002)

41. Kechavarzi, C., Dawson, Q., Leeds-Harrison, P.B.: Physical properties of low-lying agricultural peat soils in England. Geoderma 154, 196-202 (2010)

42. Gorres, J.H., Savin, M.C., Amador, J.A.: Soil micropore structure and carbon mineralization in burrow and casts of an anecic earthworm (Lumbricus terrestris). Soil Biol. Biochem. 33, 1881-1887 (2001)

43. Schjønning, P., Thomsen, I.K., Petersen, S.O., Kristensen, K., Christensen, B.T.: Relating soil microbial activity to water content and tillage-induced differences in soil structure. Geoderma 163, 256-264 (2011)

44. Yu, O., Raichle, B., Sink, S.: Impact of biochar on the water holding capacity of loamy sand soil. Int. J. Energy Environ. Eng. 4, 44 (2013)

45. Hassink, J.: Decomposition rate constants of size and density fractions of soil organic matter. Soil Sci. Soc. Am. J. 59, 1631-1635 (1995)

46. Ruhlmann, T.J., Korschens, M., Graefe, J.: A new approach to calculate the particle density of soils considering properties of the 
soil organic matter and the mineral matrix. Geoderma 130, 272-283 (2006)

47. Elvira, C., Sampedro, L., Benitez, E., Nogales, R.: Vermicomposting of sludges from paper mill and dairy industries with Eisenia andrei: a pilot scale study. Bioresour. Technol. 63, 205-211 (1998)

48. Ahmad, Q., Qazi, J.I.: Thermophilic fermentations of lignocellulosic substrates and economics of biofuels: prospects in Pakistan. Int. J. Energy Environ. Eng. 5, 94 (2014)

49. Franzluebbers, A.J., Hons, F.M., Zuberer, D.A.: Long-term changes in soil carbon and nitrogen pools in wheat management systems. Soil Sci. Soc. Am. J. 58, 1639-1645 (1994)

50. Martin, A.: Short and long-term effects of the endogeic earthworm Milsonia anomala (Omodeo) (Megascolecidae, Oligochaeta) of tropical savannas, on soil organic matter. Biol. Fertil. Soils 11, 234-238 (1991)

51. Burtelow, A.E., Bohlen, P.J., Groffman, P.M.: Influence of exotic earthworm invasion on soil organic matter, microbial biomass and denitrification potential in forest soils of the northeastern United States. Appl. Soil Ecol. 9, 197-202 (1998)

52. Hassink, J.A., Bouwman, L.A., Zwart, K.B., Brussard, L.: Relationship between habitable pore space, soil biota and mineralization rate in grassland soils. Soil Biol. Biochem. 25, 47-55 (1993)

53. Søndergaard, M., Middelboe, M.: A cross-system analysis of labile dissolved organic carbon. Mar. Ecol. Prog. Ser. 118, 283-294 (1995)

54. Song, Y., Deng, S.P., Acosta-Martınez, V., Katsalirou, E.: Characterization of redox-related soil microbial communities along a river floodplain continuum by fatty acid methyl ester (FAME) and 16S rRNA genes. Appl. Soil Ecol. 40, 499-509 (2008)

55. Lavelle, P., Melendez, G., Pashanasi, B., Shaefer, R.: Nitrogen mineralization and reorganization in casts of the geophagous tropical earthworm Pontoscolex corethrurus (Glossoscolecidae). Biol. Fertil. Soils 14, 49-53 (1992)

56. Kawaguchi, T., Iwashima, N., Masunaga, T., Hiura, T., Kaneko, N.: The role of epigeic Japanese earthworms (Megascolecidae) in soil nutrient cycling and aggregation in a deciduous oak forest soil: a long-term field experiment. Edaphologia 88, 19-30 (2011)

57. Jouquet, P., Thi, P.N., Hong, H.N., Henry-des-Tureaux, T., Chevallier, T., Duc, T.T.: Laboratory investigation of organic matter mineralization and nutrient leaching from earthworm casts produced by Amynthas khami. Appl. Soil Ecol. 47, 24-30 (2011)

58. Aguilar, O.A., Maghirang, R., Trabue, S.L., Erickson, L.E.: Experimental research on the effects of water application on greenhouse gas emissions from beef cattle feedlots. Int. J. Energy Environ. Eng. 5, 103 (2014)

59. Lavelle, P., Martin, A.: Small-scale and large-scale effects of endogeic earthworms on soil organic matter dynamics in soils of the humid tropics. Soil Biol. Biochem. 24, 1491-1498 (1992)
60. Flegel, M., Schrader, S.: Importance of food quality on selected enzyme activity in earthworm casts (Dendrobaena octaedra, Lumbricidae). Soil Biol. Biochem. 32, 1191-1196 (2000)

61. Tabatabai, M.A., Chae, Y.M.: Mineralization of sulfur in soils amended with organic wastes. J. Environ. Qual. 20, 684-690 (1991)

62. Reddy, K.S., Singh, M., Swarup, A., Rao, A.S., Sing, K.N.: Sulfur mineralisation in two soils amended with organic manures, crop residues, and green manures. J. Plant Nutr. Soil Sci. 165, 167-171 (2002)

63. Wolt, J.D.: Soil solution chemistry: applications to environmental science and agriculture. Wiley, New York (1994)

64. Phillips, I.R., Greenway, M.: Changes in water-soluble and exchangeable ions, cation exchange capacity, and phosphorus max in soils under alternating waterlogged and drying conditions. Commun. Soil Sci. Plant Anal. 29, 51-65 (1998)

65. Stepniewska, Z., Lipiec, J., Dabek-Szreniawska, M., Bennicelli, R., Stepniewski, W.: The influence of anaerobic conditions on enzymatic activity in a loess soil (Horizon Ap). Folia Soc. Sci. Lubl. 30, 53-59 (1990)

66. Brzezinâska, M., Stepniewska, Z., Stepniewski, W.: Soil oxygen status and dehydrogenase activity. Soil Biol. Biochem. 30, 1783-1790 (1998)

67. Allison, V.J., Condron, L.M., Peltzer, D.A., Richardson, S.J., Turner, B.L.: Changes in enzyme activities and soil microbial community composition along carbon and nutrient gradients at the Franz Josef chronosequence, New Zealand. Soil Biol. Biochem. 39, 1770-1781 (2007)

68. Sinsabaugh, R.L., Gallo, M.E., Lauber, C., Waldrop, M.P., Zak, D.R.: Extracellular enzyme activities and soil organic matter dynamics for northern hardwood forests receiving simulated nitrogen deposition. Biogeochemistry 75, 201-215 (2005)

69. Yao, H., Bowman, D., Rufty, T., Shi, W.: Interactions between N fertilization, grass clipping addition and $\mathrm{pH}$ in turf ecosystems: implications for soil enzyme activities and organic matter decomposition. Soil Biol. Biochem. 41, 1425-1432 (2009)

70. Poll, C., Ingwersen, J., Stemmer, M., Gerzabek, M.H., Kandelere, E.: Mechanisms of solute transport affect small scale abundance and function of soil microorganisms in the detritusphere. Eur. J. Soil Sci. 57, 583-595 (2006)

71. Kang, H., Freeman, C.: Phosphatase and arylsulphatase activities in wetland soils: annual variation and controlling factors. Soil Biol. Biochem. 31, 449-454 (1999)

72. Xiao-Chang, W., Qin, L.: Effect of waterlogged and aerobic incubation on enzyme activities in paddy soil. Pedosphere 16, 532-539 (2006) 